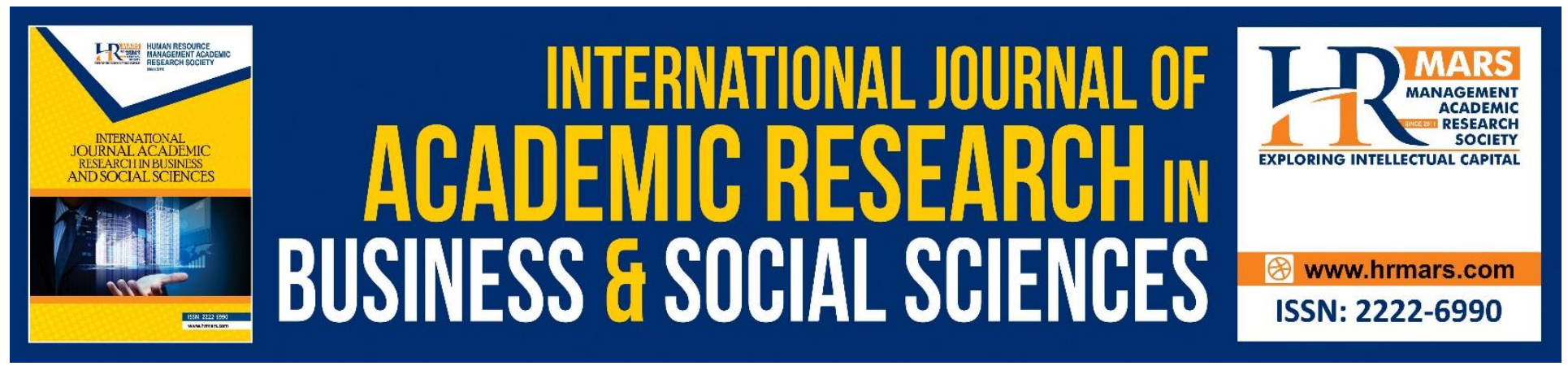

\title{
Inhibitors of Continuous Improvement on Manufacturing Performance in Export-based Furniture Industry
}

Nusaibah Mansor, Yeow Lih Jen, Siti Norbaya Yahaya

To Link this Article: http://dx.doi.org/10.6007/IJARBSS/v8-i10/5304 DOI: $10.6007 /$ IJARBSS/v8-i10/5304

Received: 03 Oct 2018, Revised: 24 Oct 2018, Accepted: 04 Nov 2018

Published Online: 07 Nov 2018

In-Text Citation: (Mansor, Jen, \& Yahaya, 2018)

To Cite this Article: Mansor, N., Jen, Y. L., \& Yahaya, S. N. (2018). Inhibitors of Continuous Improvement on Manufacturing Performance in Export-based Furniture Industry. International Journal of Academic Research in Business and Social Sciences, 8(10), 1361-1371.

Copyright: @ 2018 The Author(s)

Published by Human Resource Management Academic Research Society (www.hrmars.com)

This article is published under the Creative Commons Attribution (CC BY 4.0) license. Anyone may reproduce, distribute, translate and create derivative works of this article (for both commercial and non-commercial purposes), subject to full attribution to the original publication and authors. The full terms of this license may be seen

at: http://creativecommons.org/licences/by/4.0/legalcode

Vol. 8, No. 10, 2018, Pg. 1361 - 1371

http://hrmars.com/index.php/pages/detail/IJARBSS

JOURNAL HOMEPAGE

Full Terms \& Conditions of access and use can be found at http://hrmars.com/index.php/pages/detail/publication-ethics 


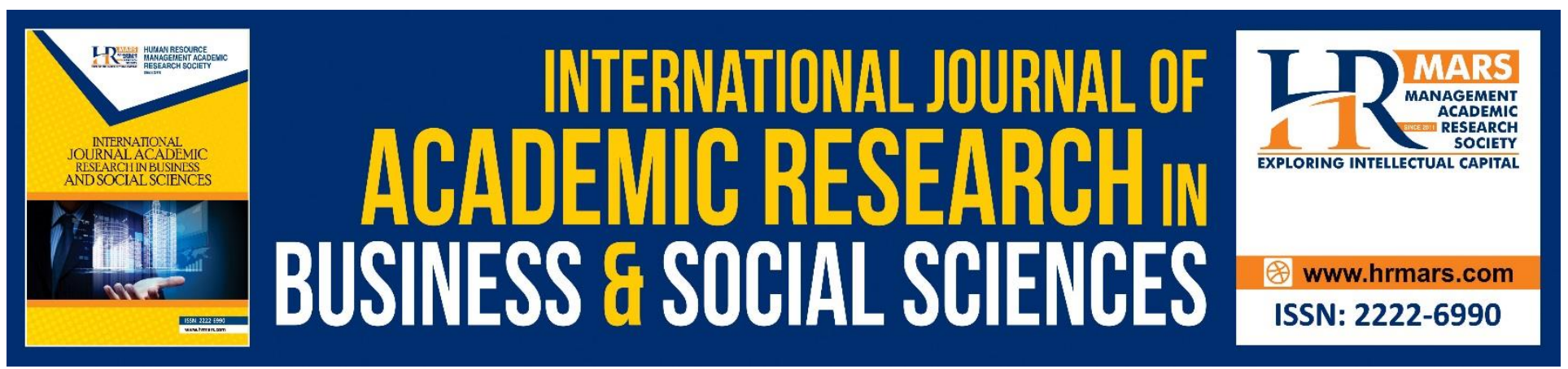

\title{
Inhibitors of Continuous Improvement on Manufacturing Performance in Export-based Furniture Industry
}

\author{
Nusaibah Mansor, Yeow Lih Jen, Siti Norbaya Yahaya \\ Universiti Teknikal Malaysia Melaka, Malaysia
}

\begin{abstract}
The Malaysia export-based furniture industry has contributed significantly to the Malaysia economy over the years. Ranked as one of top furniture country exporter, the industry starts experiencing stagnant in 2014. Dependency on producing quality products to be exported worldwide, the industry in need of continuous improvement to ensure better manufacturing performance. This research therefore aimed to study the inhibitors of continuous improvement on manufacturing performance. Quantitative approach is selected as research methodology to reach the aim of research. A total number of 200 Malaysian furniture manufacturers participated in this research using the structured questionnaire. The data obtained are analyzed using Statistical Package for Social Sciences (SPSS) computer software. Few analyses were conducted to identify the inhibitors of continuous improvement. Pearson's Correlation Analysis is deployed to study how the inhibitors influence manufacturing performance and Multiple Regression Analysis used to study the most significant inhibitor. Overall, all the five inhibitors exhibited significant positive relationship with manufacturing performance. The result of the research also revealed, out of the five identified inhibitors, measurement and information deployment influenced the most.
\end{abstract}

Keywords: Continuous Improvement, Manufacturing Performance, Furniture Industry.

\section{Introduction}

Malaysian furniture industry is growing extraordinary fast, as it ranked the top 10 list of the world's largest furniture exporter. Malaysia exports approximately $80 \%$ of its furniture production worldwide. This trend started when the Taiwanese invested in furniture companies during the early days in the 80's that have led the industry. They came for the abundance of wood resources, low labor costs and cheap land. However, with the burning desires to succeed and the strong entrepreneurial spirits in this furniture industry, many furniture manufacturers begin their own operations, some others came into the business starting as sub-contractors making components for other larger companies before going into the production of complete furniture. 
The furniture industry has made a significant contribution to the Malaysian economy. The Malaysian furniture industry had grown dynamically from the early of 80 's where it has transformed from traditional based operation to a technological driven industry. However, starting from the year of 2014 , the industry seems to be stagnant with the export revenue hovering at seven to eight billion per year for ten consecutive years with an average annual growth of only $3.98 \%$. Hence, to sustain the continuous improvement on manufacturing performance in export-based furniture industry is significantly difficult.

Continuous improvement is an essential element in a modern quality system and it aims at improving efficiency by optimizing a process and eliminating wasted efforts in production. This research is initially focused on the identification of the inhibitors of continuous improvement on manufacturing performance in export-based furniture industry. Albliwi et al., (2014) described the previous absence of research in to critical failure factors specific to industries, such as manufacturing, as a "huge gap" in research. This was addressed through the completion of a systematic literature review. This allowed the identification of five inhibitors of continuous improvement on manufacturing performance.

Even though continuous improvement has been known for decades and many books have written about its practical implementation, companies often find their continuous improvement in a fledgling state (Garcia-Sabater \& Marin-Garcia, 2011), the failure rate is still high (Bessant et.al., 2001). Companies often achieve significant improvements in the short run, but continuous improvement ultimately falls apart. Clearly, there is a need to understand why the failure rate is high and what are the inhibitors of continuous improvement contribute towards the manufacturing performance in export-based furniture industry. Therefore, this research is aimed to study the inhibitors of continuous improvement contribute towards the manufacturing performance in export-based furniture industry.

\section{Problem Statement}

The furniture industry in Malaysia is an established sector with a long history, substantial technological advancement and an established market. According to former Prime Minister Malaysia Dato' Sri Najib Razak in 2018 budget, a sum of RM100 million is provided to production of furniture industry for exports (Yee, 2017). The manufacturing performance of this industry can be considered as one of the driving forces of Malaysian economic growth because of its prominence. Malaysian furniture industry has so far successfully struggled to remain competitive worldwide (Tey, 2017). It is increasingly facing barriers of continuous improvement on its manufacturing process. However, furniture manufacturing industry is currently confronted by a number of structural inhibitors towards the continuous improvement on manufacturing performance such as a lack of training, learning and skills, cultural and environment changes, poor organizational management, process issues, limited access towards measurement and information tools (Sánchez, 2012).

In the export-based furniture industry, the production department is usually more complex and complicated than the other department of an organization. Most of the furniture companies are 
having the problems with the efficiency and effectiveness on the manufacturing performance. The export-based furniture industry's manufacturing performance has not been satisfactory in recent years. A recent market research by Malaysian Timber Council (MTC) revealed that Malaysia market share has been shrinking by $45 \%$ over the past six years due to the barriers of continuous improvement to suit United Kingdom's changing requirements, consumer preferences and distribution trends. Therefore, the inhibitors of continuous improvement will impact on the manufacturing performance in export-based furniture industry.

\section{Literature Review}

The Malaysian furniture industry has developed from a cottage-based industry in the early 1980s, supplying mainly the domestic market, to become a full-fledged export industry today, serving the world market (Ng et. al., 2012). This is because the availability and natural abundance of raw materials in Malaysia has been instrumental in the development of the furniture industry in Malaysia, especially with the advent of Malaysian oak or rubber wood as a suitable and even quality material for furniture production (Evergreen, 2003). Besides that, other contributory factors include investments in the latest production techniques, high quality furniture products at value-for-money prices in the global market, relatively low labor costs coupled with a skilled and dedicated workforce (Evergreen, 2003).

In recent years, there is now focus on the design and production of higher quality products. Attempts are being made by the industry to incorporate the latest materials, styles and trends. The growth has shifted from producing general products towards designing its own and has been key in propelling Malaysia onto the international arena. Now, a growing number of manufacturers are investing in new technology and even latest automated processes.

\section{Continuous Improvement}

Continuous improvement is not as much related to work improvement as in the early stage, but its focus is linked to comprehensive and organized methods that allow all levels of the organizations to take part in the initiatives in a sustained way (Bhuiyan \& Baghel, 2005). Over the decades, as the need to continuously improve on a larger scale within the organization became an imperative, a number of continuous improvement methodologies have developed based on a basic concept of quality improvement, process improvement or both in order to improve quality, simplify the production line and reduce waste (Bhuiyan, \& Baghel, 2005). The best known of the continuous improvement methodologies are lean manufacturing, the balanced scorecard, six-sigma, lean six sigma, Kaizen and total quality management (Chiarini, 2011; Sánchez, 2012).

The implementation of continuous improvement is not always a successful program and has been particularly difficult to maintain in the long-term period. Most of the firms face difficulties in maintaining half of the outcomes from continuous improvement applications (Laraia et al., 1999). The success of continuous improvement tools such as Kaizen show evidence of a weak learning culture that may lead to struggle during organizational change resulting the continuous improvement implementation (Doolen et. al., 2008; Van et. al., 2010). Table 1. below displays a summary of 
INTERNATIONAL JOURNAL OF ACADEMIC RESEARCH IN BUSINESS AND SOCIAL SCIENCES

Vol. 8, No. 10, Oct. 2018, E-ISSN: 2222-6990 ㄷ 2018 HRMARS

inhibitors of continuous improvement based on the current literature. The following items formed the basis of this research as independent variables and main inhibitors for continuous improvement.

Table 1. Evidence of Variables from Previous Studies

\begin{tabular}{|l|l|}
\hline \multicolumn{1}{|c|}{ Inhibitors of Continuous Improvement } & \multicolumn{1}{c|}{ Authors } \\
\hline Leadership & $\begin{array}{l}\text { Bessant et al., 1994 } \\
\text { Irani et al., 2002 } \\
\text { Varghese, 2004 }\end{array}$ \\
\hline Measurement and Information deployment & $\begin{array}{l}\text { Bessant et al., 1994 } \\
\text { Rich \& Bateman, 2003 } \\
\text { Sanchez, 2012 }\end{array}$ \\
\hline Training, learning and skills & $\begin{array}{l}\text { Dale et al., 1997 } \\
\text { Oliver, 2009 }\end{array}$ \\
\hline Process Issue & $\begin{array}{l}\text { Kerrin, 1999 } \\
\text { Belen, 2004 } \\
\text { Bateman, 2005 }\end{array}$ \\
\hline Cultural Issue & $\begin{array}{l}\text { Kaye \& Anderson, } 1999 \\
\text { Van et al., 2010 } \\
\text { Marksberry et al., 2010 }\end{array}$ \\
\hline
\end{tabular}

\section{Theoretical Framework}

This research based on the broad review of the documented empirical studies on the relationship between independent and dependent variables. The independent variables in this research are leadership, measurement and information deployment, training learning and skills, process issue, and cultural issue. The dependent variable is the manufacturing performance. Figure 1 shows the framework for this research: 


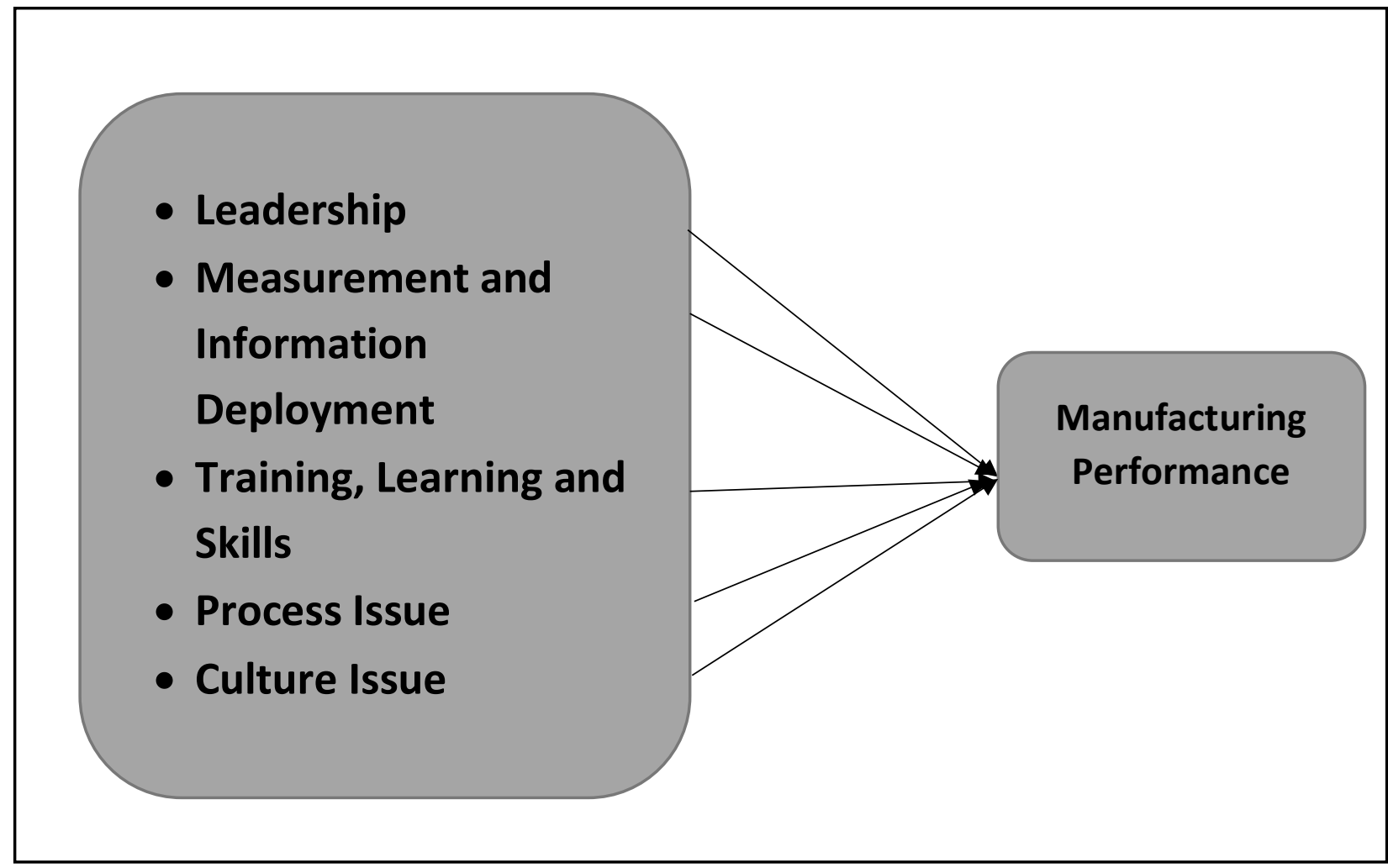

In this study, explanatory research is the most suitable research design because it looks for explanation of the nature of certain relationship. Explanatory research is used to study the relationship between the independent variable and dependent variable in this study. The independent variables that been identified are the inhibitors of continuous improvement, while the dependent variable is the manufacturing performance.

\section{Methodology}

Quantitative approach in this research is used to identify the inhibitors of the continuous improvement in providing the good performance of manufacturing process in export-based furniture industry. A quantitative approach is necessary for this study as the nature of the research questions required the specific variables be carefully analyzed. A set of critical inhibitors would be provided and given out to the respondents. Researchers prepared structured questionnaire based on identified inhibitors. Likert scale is selected as the measurement for this study. A reliability test is conducted before hand using Cronbach's Alpha with high degree of reliability of $86 \%$. After that, respondents were given a set of questionnaires in order to determine the perspective or attitudes of respondents towards the inhibitors of continuous improvement. A total 373 set of questionnaires are distributed to Malaysian furniture manufacturer during Malaysia International Furniture Fair (MIFF). At the end, researchers managed to obtain in total 200 questionnaires. 
INTERNATIONAL JOURNAL OF ACADEMIC RESEARCH IN BUSINESS AND SOCIAL SCIENCES

Vol. 8, No. 10, Oct. 2018, E-ISSN: 2222-6990 ㄷ 2018 HRMARS

\section{Findings}

Data analysis provided the result of inferential analysis which consists the correlation analysis that describe the degree of relationship between independent variables and dependent variables. This is to answer the research objective and followed by multiple regression analysis. This is to answer the research objective of the researcher which is to identify the most significant inhibitor of continuous improvement on manufacturing performance in export-based furniture industry.

\section{Correlation Analysis}

The following Table 2 shows the correlation between the inhibitors of continuous improvement towards the manufacturing performance for export-based furniture industry. The table shows the correlation is significant at 0.01 level and this can prove that all five inhibitors of continuous improvement have efficiency of $p$-value $<0.01$.

Table 2. Relationship between inhibitors and manufacturing performance

\begin{tabular}{|l|c|}
\hline Independent Variables & Manufacturing Performance \\
\hline Leadership Information & $.414^{* *}$ \\
\hline $\begin{array}{l}\text { Measurement and } \\
\text { deployment }\end{array}$ & $.583^{* *}$ \\
\hline Training, learning and skills & $.525^{* *}$ \\
\hline Process Issue & $.543^{* *}$ \\
\hline Cultural Issue & $.518^{* *}$ \\
\hline$* * p<0.01$ & \\
\hline
\end{tabular}

Based on Table 2, it shown that there is a significant positive and strong relationship between all five independent variables (leadership, measurement and information deployment, training learning and skills, process issue and cultural issue) and dependent variable (manufacturing performance) which the correlation coefficient is all range of 0.40 to 0.60 .

\section{Multiple Regression Analysis}

Table 3 illustrates the results of the regression equation coefficients for the independent variables and dependent variable (manufacturing performance). The regression coefficient value of the expected value for manufacturing performance when independent variables become zero, stated as $\mathrm{R}=651$. This value indicates strong correlation between all independent variables and manufacturing performance. 
INTERNATIONAL JOURNAL OF ACADEMIC RESEARCH IN BUSINESS AND SOCIAL SCIENCES Vol. 8, No. 10, Oct. 2018, E-ISSN: 222 2-6990 @ 2018 HRMARS

Table 3. Multiple Regression Analysis

\begin{tabular}{|c|c|c|c|c|}
\hline Inhibitors & $\beta$ & t-value & F-value & R-square \\
\hline Leadership & -0.146 & -1.775 & \multirow{5}{*}{28.514} & \multirow{5}{*}{0.424} \\
\hline $\begin{array}{l}\text { Measurement and } \\
\text { Information deployment }\end{array}$ & 0.330 & 3.862 & & \\
\hline Training, learning and skills & 0.103 & 1.176 & & \\
\hline Process Issue & 0.247 & 3.044 & & \\
\hline Cultural Issue & 0.200 & 2.491 & & \\
\hline
\end{tabular}

In addition, the value of $\mathrm{R}$-square is .424 , which counted $42.4 \%$ variability of independent variables (leadership, measurement and information deployment, training learning and skills, process issue and cultural issue) supported manufacturing performance. In other words, all factors of continuous improvement have contributed $42.4 \%$ into the manufacturing performance while remaining of $57.6 \%$ is indirect influenced by other factors into other performances improvement in the organization.

ANOVA assessed the overall significance of the model. The model is significance because the F-test value is 28.514 , where $p$-value $<.001$. In ANOVA analysis, the model is significance when $p$-value < .001 and means that the regression is fit and good data in this research study. This research study shown that the manufacturing performance can influence by all the inhibitors of continuous improvement. It can be concluded that the predictor independent variables which are leadership, measurement and information deployment, training learning and skills, process issue and cultural issue have significance relationship towards manufacturing performance that consisted of delivery performance, quality performance, cost performance and flexibility performance.

Based on the coefficient value, it shows that there is positive relationship between independent variables (measurement and information deployment, training learning and skills, process issue and cultural issue) and dependent variable (manufacturing performance), but only the leadership has negative relationship with manufacturing performance. The regression coefficient for the independent variables is interpreted as when there is every unit increase in independent variables, it will lead to the manufacturing performance increase by 0.330 units of measurement and information deployment, 0.103 units of training learning and skills, 0.247 units of process issue and 0.200 units of cultural issue. The regression equation is written as follows:

Manufacturing Performance $=1.360-0.146$ (leadership) +0.330 (measurement and information deployment) +0.103 (training learning and skills) +0.247 (process issue) + 0.200 (cultural issue) 
According to the result, one of the independent variables from the inhibitors of continuous improvement, which is measurement and information deployment influence the most to manufacturing performance rather than the other four inhibitors of continuous improvement. Measurement and information deployment has the highest value rather than other inhibitors, where $\beta=.330, t(200)=3.862$ and $p<0.05$.

\section{Conclusion}

From the findings it has depicted manufacturing performance has strong relationship with identified inhibitors namely leadership, measurement and information deployment, training learning and skills, process issue and cultural issue. This further strengthen previous studies (Rich \& Bateman, 2003; Sánchez, 2012) measurement and information deployment as one of the inhibitors is very crucial in demonstrating that continuous improvement oriented firms, value systematic progress and regularly measure progress against stated goals. This systematic progress enables the business to evaluate the processes' effectiveness and manage the firm effectively by sharing proven successful solutions or setting new course of action. Lack of measurement, no feedback system, inadequate information and analysis can be the most significant factors lead to the failure of measurement and information deployment as one of the inhibitors of continuous improvement.

\section{Acknowledgement}

Authors wish to thank Universiti Teknikal Malaysia Melaka for providing resources and facilities to carry out this research.

\section{Corresponding Author}

Nusaibah Mansor

Universiti Teknikal Malaysia Melaka, Malaysia

nusaibah@utem.edu.my

Faculty of Technology Management and Technopreneurship

Universiti Teknikal Malaysia Melaka

Hang Tuah Jaya, 76100 Durian Tunggal,

Melaka, Malaysia.

\section{References}

Albliwi, S., Antony, J., Abdul Halim Lim, S., \& Van der Wiele, T. (2014). Critical Failure Factors of Lean Six Sigma: A Systematic Literature Review. International Journal of Quality \& Reliability Management, 31(9), 1012-1030.

Bateman, N. (2005). Sustainability: The Elusive Element of Process Improvement. International Journal of Operations \& Production Management, 25(3), 261-276.

Belén Escrig-Tena, A. (2004). TQM As A Competitive Factor: A Theoretical and Empirical Analysis. International Journal of Quality \& Reliability Management, 21(6), 612-637. 
INTERNATIONAL JOURNAL OF ACADEMIC RESEARCH IN BUSINESS AND SOCIAL SCIENCES

Vol. 8, No. 10, Oct. 2018, E-ISSN: 2222-6990 ㄷ 2018 HRMARS

Bessant, J., Caffyn, S., \& Gallagher, M. (2001). An Evolutionary Model Of Continuous Improvement Behaviour. Technovation, 21(2), 67-77.

Bessant, J., Caffyn, S., Gilbert, J., Harding, R., \& Webb, S. (1994). Rediscovering Continuous Improvement. Technovation, 14(1), 17-29.

Bhuiyan, N., \& Baghel, A. (2005). An Overview of Continuous Improvement: From the Past to the Present. Management Decision, 43(5), 761-771.

Chiarini, A. (2011). Japanese Total Quality Control, TQM, Deming's System of Profound Knowledge, BPR, Lean and Six Sigma: Comparison and Discussion. International Journal of Lean Six Sigma, 2(4), 332-355.

Dale, B., Boaden, R., Wilcox, M., \& McQuater, R. (1997). Sustaining Total Quality Management: What Are The Key Issues? The TQM Magazine, 9(5), 372-380.

Doolen, T. L., Van Aken, E. M., Farris, J. A., Worley, J. M., \& Huwe, J. (2008). Kaizen Events and Organizational Performance: A Field Study. International Journal of Productivity and Performance Management, 57(8), 637-658.

Garcia-Sabater, J. J., \& Marin-Garcia, J. A. (2011). Can We Still Talk About Continuous Improvement? Rethinking Enablers And Inhibitors For Successful Implementation. International Journal of Technology Management, 55(1/2), 28-42.

Irani, Z., Choudrie, J., Love, P. E., \& Gunasekaran, A. (2002). Sustaining TQM Through Self-Directed Work Teams. International Journal of Quality \& Reliability Management, 19(5), 596-609.

Kaye, M., \& Anderson, R. (1999). Continuous Improvement: The Ten Essential Criteria. International Journal of Quality \& Reliability Management, 16(5), 485-509.

Kerrin, M. (1999). Continuous Improvement Capability: Assessment Within One Case Study Organisation. International Journal of Operations \& Production Management, 19(11), 11541167.

Laraia, A. C., Moody, P. E., \& Hall, R. W. (1999). The Kaizen blitz: accelerating breakthroughs in productivity and performance: John Wiley \& Sons.

Marksberry, P., Badurdeen, F., Gregory, B., \& Kreafle, K. (2010). Management Directed Kaizen: Toyota's Jishuken Process for Management Development. Journal of Manufacturing Technology Management, 21(6), 670-686. 
INTERNATIONAL JOURNAL OF ACADEMIC RESEARCH IN BUSINESS AND SOCIAL SCIENCES

Vol. 8, No. 10, Oct. 2018, E-ISSN: 2222-6990 ㄷ 2018 HRMARS

Ng, B. K., Chandran, V. G. R., \& Kanagasundram, T. (2012). Technological Knowledge, Learning And Linkages in The Wooden Furniture Industry in Malaysia: A Spatial Innovation Perspective. Asian Journal of Technology Innovation, 20(2), 187-200.

Oliver, J. (2009). Continuous Improvement: Role Of Organisational Learning Mechanisms. International Journal of Quality \& Reliability Management, 26(6), 546-563.

Rich, N., \& Bateman, N. (2003). Companies' Perceptions of Inhibitors And Enablers For Process Improvement Activities. International Journal of Operations \& Production Management, 23(2), 185-199.

Sánchez, J.M. (2012). Assessing Sustainability of the Continuous Improvement Through the Identification of Enabling and Inhibiting Factors. Doctor of Philosophy, Virginia Polytechnic Institute and State University.

Tey, K. (2017, June 20). Strengthening the furniture industry. The Star Online. Retrieved from https://www.thestar.com.my/metro/community/2017/06/20/strengthening-the-furnitureindustry-threeday-fair-serves-as-platform-to-promote-products-for-export/

Van Aken, E. M., Farris, J. A., Glover, W. J., \& Letens, G. (2010). A Framework for Designing, Managing, and Improving Kaizen Event Programs. International Journal of Productivity and Performance Management, 59(7), 641-667.

Varghese, C. (2004). Resolving The Process Paradox: A Strategy for Launching Meaningful Business Process Improvement. Cost Engineering, 46(11), 13-21.

Yee, L. H. (2017, October 27). Budget 2018: Full speech. The Star Online. Retrieved from https://www.thestar.com.my/news/nation/2017/10/27/budget-2018-full-speech/ 